\title{
Professional and personal strategies of documentary filmmakers in Brazil: the case of the State of Rio de Janeiro and Minas Gerais.
}

\author{
Anne-Marie Autissier, \\ Université Paris 8
}

\begin{abstract}
Between 2012 and 2019, this qualitative sociological research was part of a documentary "boom" moment in Brazil, in terms of production and international recognition. Faced with a bottleneck in terms of their distribution, a growing number of festivals have opened up for documentaries, not counting the historical festival "É tudo Verdade" (São Paulo). This period also corresponds to a time when attempts at policies in favor of documentary films were made by the Federation and the Ministry of Culture (MinC) - public channel TV Brasil, TV Cultura, Doc.TV... These various advances have allowed the expression of a "black" cinema (Joel Zito Araujo), LGBT concerns (Karla Holanda), women's rights (Helena Solberg and Susanna Lira) and the possibility for indigenous people to seize digital tools to reflect their own realities (Vincent Carelli, Video nas aldeias). Thus, while the Brazilian authorities were carrying out unfinished policies facing the weight of the private oligopolistic sector, it was interesting to analyze how documentary filmmakers developed their professional strategies. From this perspective, fourteen directors were the subject of semi-structured interviews in the state of Rio de Janeiro and three in Minas Gerais. In addition, producers and festival managers were also contacted. But the arrival of the Bolsonaro government caused a real rift. Against a backdrop of cultural war, fake news aimed at discrediting artistic circles, the takeover of the National Cinema Agency (ANCINE) and the abandonment of the São Paulo film library, cuts from major corporate sponsors, and beyond, Brazilian documentary filmmakers have found themselves strangers in their own country.
\end{abstract}

Keywords: Brazilian documentary film, cultural policies, cinema and audiovisual policies, cinema and audiovisual funding, Brazilian culture.

Résumé: Entre 2012 et 2019, cette enquête sociologique qualitative s'est consacrée au « boom » du documentaire au Brésil, à la fois en termes de production et de reconnaissance internationale. Face à un blocage lié à la diffusion/distribution, un nombre croissant de festivals se sont ouverts au documentaire, sans oublier l'expérience historique du festival É Tudo Verdade à São Paulo. Cette période correspond aussi à un moment où des initiatives publiques ont été menées en faveur du documentaire, par la Fédération et le ministère de la Culture brésilien (MinC) : TV Brasil, TV Cultura, Doc. TV. Ces différentes avancées ont notamment permis l'expression d'un " cinéma noir » (Joel Zito Araujo), des questions afférentes aux LGTB (Karla Holanda), aux droits des femmes (Helena Solberg et Susanna Lira) et des possibilités pour les peuples aborigènes de se saisir d'outils numériques pour exprimer leur propre réalité (Vincent Carelli, Video nas aldeias). Ainsi, les autorités brésiliennes ont conduit des politiques intéressantes mais inachevées face au poids du secteur oligopolistique privé. Les

Anne-Marie Autissier is a Sociologist and Emeritus Lecturer at Université Paris 8 and CRESPPA. Email : amautissier@wanadoo.fr

Culture and Local Governance / Culture et gouvernance locale, vol. 7, no. 1-2, 2020. ISSN 1911-7469 Centre on Governance, University of Ottawa, 120 university, Ottawa, Ontario, Canada K1N 6N5 
documentaristes brésiliens ont développé leur propres stratégies - formation, production, distribution. Dix-sept réalisateurs et réalisatrices ont ainsi été interviewés lors de cette recherche, quatorze dans l'État de Rio et trois dans le Minas Gerais. Cependant, l'arrivée du gouvernement Bolsonaro a créé un véritable raz-de-marée: outre la disqualification des milieux culturels, une sorte de " censure préalable " qui ne dit pas son nom et pourtant interdite par la Constitution brésilienne, s'est fait jour. L'article rend compte de la situation des documentaristes brésiliens avant cette période et des conséquences ultérieures sur leur situation, alors que soudain ils/elles étaient devenu soudain étrangers dans leur propre pays, cependant soutenu par un mouvement international d'ampleur.

Mots clé: Film documentaire brésilien, politiques culturelles, politiques du cinéma et de l'audiovisuel, financements du cinéma et de l'audiovisuel, culture brésilienne.

\section{Introduction}

The qualitative survey, the results of which are described below, was carried out between 2012 and 2019. It consisted of semi-structured interviews with seventeen directors, as well as the delivery of a questionnaire to which some of them responded. The choice of these people was established after consultation with producers, festival managers, academics, editors of specialized magazines, and the directors themselves. The stipulation being the chosen participants produced and disseminated their works professionally, and some or most of their income was based on their creative commitment. I would like to make a point regarding my methodology: as a sociologist, my main interest lies in the interactions between public/private cultural policies and culture professionals. Hence this article is mainly based on professionals' perceptions of the Brazilian cinematographic and audiovisual context. This choice may seem "impressionist", however it speaks to our empirical approach, by highlighting individual expectations and motivations, without neglecting the interdependence of artistic activities and the resulting "division of labor"1.

Also intentional was the comparative study of two states - the State of Rio de Janeiro and Minas Gerais, for their similarity in terms of professional requirements and their disparity around access to notoriety and international contacts, despite efforts made by Minas Gerais to help its cinematographic and audiovisual production ${ }^{2}$. More generally, disparity between production and diffusion/distribution was observed in both states. The upheavals that affected Brazilian political life between 2012 and 2019, of course, formed an important part of the strategic environment in which professionals evolved. The recent measures taken by the government of Jair Bolsonaro, aimed at destabilizing cultural circles, particularly those in the cinema and audiovisual sectors, were taken into account in this investigation ${ }^{3}$. This work was supported by CRESPPA, a joint research unit of which the author is a member ${ }^{4}$. 
Identity or unfinished identity?

We started with a reflection by Francisco Elinaldo Teixeira in the collective work he edited, Documentário no Brasil: Tradição e transformação 5 .

In it, the author noted that in the 1980s, the designation "documentary filmmaker" constituted half an identity (meia-identidade), undermined by the competition with major art and fiction.

But what fiction? Two traditions coexist in Brazil: one is entertainment-based (comedies from the 1920s) and the other, notably that of Cinema Novo (Glauber Rocha et alii), is radical and reflexive, a cinema of denunciation and criticism.

The second Brazilian dictatorship (1964-1985) and its influence on cultural potential (cinema, audiovisual and music) is substantial, as indicated by the establishment of Rede Globo, a private television company which was financed initially by public authorities ${ }^{6}$. According to journalist and professor Christina Ferraz Musse, the Rede Globo is the privileged, dominant and far-reaching entrepreneurial arm of national integration, the fabric of Brazilian identity; that is, a decolonized but colonialist identity: a white perspective of Brazilian society, where blacks are servants, and the indigenous are absent from the cast. Even today, according to Cristiano Rodriguez, then documentary film producer in Minas Gerais, the Rede Globo stifles all alternative space and contaminates the aesthetics of Brazilian fiction films ${ }^{7}$.

Director and essayist Joel Zito Araujo comments:

"All existing studies show that telenovela, like Brazilian cinema, has always rejected a representation of Brazilian racial diversity, for a white minority country with a population of Afro-descendants made up of Blacks and mestizos, which corresponds to $54.9 \%$ of a total population of 205 million inhabitants, according to the last census of 2016 carried out by the IBGE, the official statistics body of the Brazilian state. ${ }^{8 \prime \prime}$

Another initiative during these years was the creation of Embrafilme in 1969, a semi-public company intended to manage the entire cinema chain, so as to be less dependent on American majors and represent Brazil abroad.

\section{Documentary: a trompe-l'oeil boom?}

A few years after the end of the dictatorship, a working-class trade unionist, Luiz Inácio Lula da Silva, was elected, and from 2011, Dilma Roussef, a former member of the resistance during the dictatorship years, took over. But some Brazilian sociologists warned: neither Lula nor Roussef were representative of their constituents.

In the meantime, several circumstances combined to facilitate Brazilian documentaries: the development of video from the 1980s, and later, the Internet. Mariana Ferraz Musse reports on the following: "The increase in documentary production in Brazil is due, in large part, to cheaper devices and equipment, mainly in the last decade of the 1990s (...) Another device that has contributed to the increase in audiovisual production is the incorporation of less complex programs on computers, 
as well as more practical and faster non-linear tools. Thanks to technical development, a space has been opened up for the democratization of production and in a less professional, but no less relevant way, so that each individual can portray "his/her world". ${ }^{9}$ "

This new approach to social reality is outlined by the psychoanalyst and essayist Suely Rolnik, who puts into perspective the contributions of both Tropicalism ${ }^{10}$ and Marxism without opposing them, and credits the University of Vincennes - Paris 8 for supporting her to conceive of the "poetic and political" together:

"In Brazil, I was very involved in the counter-culture, as a student of social sciences at the University of São Paulo (USP). Endowed with a Marxist education since my birth, and, at the same time, a Jewish family formation, I found myself halfway between macro- and micro-politics and the Brazil of that time left no room for this double belonging."

Suely Rolnik adds:

"Traditionally, micro-politics have been confined to artistic practices and macropolitics to activism. In my opinion, this is why the 1960 s was the scene of a very powerful, unforgettable collective experience; this is not to make an object of heroism; what matters is the memory of a radical experience which was able to combine the poetic with politics and which is still present in our bodies ${ }^{11}$."

Actually, this logic of counter-culture which includes Tropicalism, was assumed by Gilberto Gil, Minister of Culture of the Lula government between 2003 and 2008, in his declarations and acts on Brazilian culture: "Tropicalism proposed - and to a good extent succeeded - to include in political discussions, everyday issues then considered " bourgeois" and "alienated"; Also on the political agenda were the roles of women in society, sexual freedom, homosexuality and free love ${ }^{12}$."

The artistic renewal of the genre has also played a role with films like Cabra Marcado para Morrer by Eduardo Coutinho, produced in 1984, but initiated long before ${ }^{13}$. Let's not forget the role of filmmaker Silvio Tendler with Anos JK - Uma Trajetória política in 1980, then O Mundo Mágico dos Trapalhoẽs in 1981, a family documentary devoted to a troupe of artists. Director Theresa Jessorum really liked the way it was made, which she found very innovative ${ }^{14}$. $O$ Mundo Mágico dos Trapalhoẽs had 1.8 million viewers, which was an enormous success for a documentary film.

According to Mariana Ferraz Musse,

"the Brazilian documentary genre has seen, in the country, a considerable increase in the productions made (in the number of films), cinemas have opened up more space for this genre, and, on several occasions, the number of these films at festivals surpassed fiction. Television programming has given more prominence to this documentary format, especially in the use of language and aesthetic features incorporated, for example in news bulletins: live flashes, stock footage, camera in hand, intimate interviews are just a few examples. ${ }^{15 \prime \prime}$ 
This is what Ismail Xavier calls documentary film's "anthropological shift", based on listening ${ }^{16}$.

According to Filme B, starting in 2007, documentary was the second major genre in terms of numbers launched in the Brazilian market. Cartola - Musica para os olhos (Lirio Ferreira and Hilton Lacerda), Pro dia nascer feliz (João Jardim) and Santiago (João Moreira Salles) had more than 50,000 spectators ${ }^{17}$. Director of the São Paulo É Tudo Verdade festival, Amir Labaki confirmed the trend in 2007:

\footnotetext{
"It's a very good time for documentaries in Brazil, with young directors. It's a genre in itself. The country has a real tradition of documentaries. But now a generation intends to establish itself as documentary filmmakers. ${ }^{18 \prime}$
}

However, major broadcasting / distribution problems remained: at the end of 2005, out of 34 Brazilian feature-length documentaries produced, less than 14 had been distributed. According to researcher Helena Sroulevich, between 1995 and 2009, 666 feature films were made in Brazil, including 178 documentaries. Out of 138 million viewers, 3.5 million have seen documentaries ${ }^{19}$. The distribution remains limited by the decentralization of production processes without the decentralization of diffusion / distribution of products. Audiences' absence of information and the lack of distribution are locked in a vicious circle. In 2008, the documentary films claimed only $1.2 \%$ of total receipts. Already quoted, Amir Labaki confirmed the disparity between large regions of Brazil: "The north, the north-east, and the center-west are the regions which receive the least support from the BNDES (O Banco Nacional do Desenvolvimento, the national bank for development) and the Federation. ${ }^{20 \prime}$ And the Doc.TV program, an initiative of the Federation which was active from 2003 to 2010, clearly found itself struggling with these problems; we will come back to them later.

\section{What are the strategies for documentary filmmakers? At the source of the profession}

In this post-dictatorship situation, documentary filmmakers, mostly from the middle class, have to choose between:

- The history of politics in Brazil and South America ${ }^{21}$;

- The denunciation of persistent inequalities in Brazil - social documentary;

- Support for singular trajectories in the global social context;

- The daring artistic video-art approach;

- The transmission of technical and aesthetic means of realization to the communities of the territory (Indians, faveleros...). 
In this context, what strategies are available for documentary filmmakers to establish their creation? Three criteria emerged from our surveys: training and socialization; the sources of financing and the mode of management; public access and notoriety.

\section{Training and socialization: a sometimes-contradictory movement}

According to Alfredo Suppia, professor and researcher at the Federal University of Juiz da Fora (UFJF), apprentice "documentary filmmakers" receive their training in sociology, journalism, and economics. Few schools exist for the production and the technique: USP (São Paulo), UFF (Federal Fluminense University, Niteroj, Rio State). But nothing specialized for the documentary. The training is therefore eclectic and a small part comes from dedicated schools. A special mention for the San Antonio de los Baños International School of Cinema and Television (EICTV) in Cuba. A privileged choice alongside England, Canada and France (FEMIS). Among other directors trained in Cuba in our sample: Marcos Pimentel and Eryk Rocha. In 2014, director Karla Holanda indicated the growing interest in documentary study, including the existence of writing scholarships at the Federal University Fluminense (Niteroj, Rio) ${ }^{22}$. It is important to mention Eduardo Coutinho, who died in $2014,{ }^{23}$ a personality who trained at the IDHEC in France and later joined Cinema Novo; he was a school of his own for his assistants who have since become directors themselves.

In a country dominated for a long time by private or corporatist interests, the notion of public television remains foreign, despite the 2007 creation of TV Brazil. It is perhaps in Cuba and certainly in France that the notion of public service is most present. Indeed, Karla Holanda regrets that public service broadcasting or that even the very notion of public service is not taught in Brazilian schools and universities where training tends primarily towards the study of the cinematographic and audiovisual market ${ }^{24}$.

Let us now examine the training and modes of socialization of our interviewees: Consuelo Lins studied at the communication school of the Rio de Janeiro Federal University, UFRJ. She is also a graduate of the Rio PUC. She worked for six years as a journalist in Globo, Bandeirantes, and Manchette. She received a PhD from Université de Paris 3 (Sorbonne Nouvelle), having written her dissertation on documentary films, focusing on the work of American filmmaker Robert Kramer. She worked with João Moreira Salles, Cao Guimarães and Eduardo Coutinho. She joined the UFRJ as a teacher in 1996 and started making documentaries with her students ${ }^{25}$.

Sergio Bloch considers himself self-taught. He worked in theatre and then television as a cameraman in the years 1982/1983. He says he could have made a living from it. He has made corporate films and discovered the power of documentaries, notably with the films of American director Barbara Kopple and Mississippi Blues by Bertrand Tavernier and Robert Parrish, set in the southern United States (1984). He spent time in France and watched a lot of documentary films at the Beaubourg Center video library ${ }^{26}$.

Christina Grumbach studied journalism because her parents were against her studying cinema. Its biggest academy: ten years of collaboration with Eduardo Coutinho. She wants to continue her training and above all, find think tanks in which she can describe and compare her work ${ }^{27}$. 
Joel Pizzini studied in Cuiabá, capital of Matto Grosso. His grandfather, a dentist, had a projector and films. Pizzini studied engineering but became interested in journalism and social sciences. And the highlight of his studies was the university film club ${ }^{28}$.

Deborah Herszenhut worked at the Rio Film Festival as a volunteer. She lived outside of Brazil, in Portugal and Spain. She took her first film course in Lisbon, mainly for the technical aspects. She returned to Rio and to the Federal University of Rio de Janeiro (UFRJ) where she worked in productions. She also discovered visual anthropology, through the UFRJ and Varan workshops ${ }^{29}$.

Coming from a medical family, Marcos Pimentel was under great pressure to study medicine. He engaged in law and gave up, then advertising, then psychology (CES-JF) and studied journalism and social communication for a year (Federal University of Juiz da Fora, UFJF). He became a radio / TV producer and participated in the making of clips and fiction films. This was his first contact with the documentary genre. In Rio de Janeiro, he took free courses as an auditor and then joined the International School of Cinema and Television of San Antonio de Los Baños (Cuba). He majored at the Baden-Wurtenberg Film Academy (Germany) in 2004-2005, and in December 2005, he returned to Brazil. He now gives classes in Cuba twice a year ${ }^{30}$.

Teresa Jessorum was unable to study cinema: "My family wanted me to be a civil servant". She studied history and geography, and also took up photography. For seven years, she has been a script writer and photographer for fifteen feature films. There were very few documentaries at the time. At the Rio Film Festival, the screening of Cabra Mercado para Morrer was a revelation for her. She then worked for sixteen years in programming for TV Globo where she was a production assistant and director ${ }^{31}$.

Belisario Franca studied at the Jesuit school in San Ignacio and then at the Pontifical University of Rio de Janeiro - PUC (photography studies). He opened his first studio in the late $1970 \mathrm{~s}^{32}$.

In 1997, Eryk Rocha presented himself to the Cuba Film School, in San Antonio de Los Baños in Cuba. He was 19, a year younger than the required age. He stayed there for two years. Even if the experience was not totally what he expected, he did meet a few excellent people there. He studied editing (Eisenstein) and directing, and he describes the main layers of experience of this first journey: encounters of love and friendship; the discovery of a master for sound (French sound engineer Antoine Bonfanti), meeting with an exceptional editor ${ }^{33}$.

Helena Solberg had a catholic education at the French Catholic School in Rio de Janeiro. She studied Romance literature and languages at the Pontifical Catholic University of Rio de Janeiro (PUC). She wanted to be a writer. In 1971, she had to move to the United States with her first American husband. Based in the United States, she investigated Chile and Nicaragua for American TV. Through these films, she discovered her Latin American identity and the political aspect of her work was greatly enriched ${ }^{34}$.

Born in Paraíba and son of historian José Joffily Bezerra de Mello, José Joffily was a freelance photographer for various magazines - O cruzeiro, Realidade, Placar - before making his own short films. He has a master's degree in Communication from the Federal University of Rio de Janeiro (UFRJ) and was a teacher for twenty years, at the Film and Video Department of the Federal University of Fluminense ${ }^{35}$. 
Silvio Tendler created a film club at the age of sixteen, then in 1968, he was elected president of the Federation of Rio film clubs. He organized $16 \mathrm{~mm}$ screenings in the favelas which inspired him to make political films. In 1972, he visited Chile and later decided to go to study cinema in France. "At that time, France was a place of reference, " he underlines. Unifrance Films presented films at the Maison de France, among others... Godard, Bresson, Lelouch. In France, he studied history and cinema at the École Pratique des Hautes Études. He worked with Chris Marker, Armand Mattelart, Jean Rouch and Joris Ivens. What interested him was exploring the relationship between history and cinema. He also quoted Santiago Alvares Roman, a Cuban filmmaker ${ }^{36}$.

Karla Holanda has worked with cinema and video since 1992, when she moved to Rio de Janeiro to study cinema and audiovisual at Federal Fluminense University (Niteroj, Rio de Janeiro). In 1995, she attended the newly created Dragão do Mar Institute (Dramaturgy and Directing in Cinema and TV) in Fortaleza, and subsequently founded the production company Em Foco Multimídia. In 2003, she started a master's degree in Multimeios, at Unicamp, where she developed research on Northeastern documentary, under the guidance of Professor Fernão Ramos, a survey previously unheard of in the Northeast states. The dissertation resulted in the book Documentário nordestino. Mapeamento, historia e análise, published in 2008 by Annablume, with support from the São Paulo research foundation FAPESP. Since 2008, she has been living in Rio de Janeiro, where she completed a PhD at Federal Fluminense University, developing research on Brazilian documentary (DocTV: independent production on television), under the guidance of Professor Tunico Amancio. Her research has been published under the title: DOCTV: a independente producão na televisão. Um projecto de regionalização do governo Lula. After teaching at UFJF (Juiz da Fora Federal University), she currently teaches at Fluminense University. Given the fact the documentary market is difficult, being a university professor affords a more secure existence, she said. However, Karla Holanda also enjoys writing about cinema and audiovisual, as well as transmitting her knowledge and experience to young people.

With an architect mother who loved cinema and filmed a lot in Super 8, Marilia Rocha studied at the Pontifical University of Belo Horizonte. She was already making films during her master's degree. She completed her studies at the Federal University of Minas Gerais (UFMG, Belo Horizonte), in the Department of Communications, Audiovisual and Cinema, which, according to her, has since developed a $\operatorname{lot}^{38}$.

Emilio Domingos is of a middle-class upbringing with a guardian father.

"I moved between circles. It was difficult to enter University. I wanted to work with cinema and the social sciences. I like to think about unique situations. I chose anthropology for this reason, he explains ${ }^{39}$."

Lucia Murat studied economics in the 1960s at the Federal University of Rio de Janeiro (UFRJ). Very quickly, she became vice-president of the student movement. She was jailed initially for a week. In December 1968, she joined the armed resistance, and she was imprisoned for three and a half years in Rio (Vila militar) then in Bahia. She was released in $1975^{40}$. 
Susanna Lira studied audiovisual and journalism in the Communications Program of Hélio Alonso Integrated Faculties in Rio de Janeiro, a private university. She also attended international human rights law courses ${ }^{41}$.

In 2012, Mariana Ferraz Musse studied communications as part of a master's in Documentary and Society at the Higher School of Cinema and Audiovisual, ESCAC in Barcelona (Spain). She completed her master's degree at the Federal University of Juiz da Fora, with a dissertation devoted to Brazilian documentary, which we have had the pleasure of quoting. From 2012 to 2016, she completed a PhD in communications at the Popeu Fabra University in Barcelona. She also has a journalistic background. She teaches at the University of Juiz da Fora ${ }^{42}$.

\section{Funding and management strategies}

During our interviews on May 30/31 and June 1, 2012, in Juiz da Fora, producer Christiano Rodriguez along with professors Christina Ferraz Musse and Alfredo Suppia, underlined the broadcasting and remuneration possibilities available to documentary filmmakers. Aside from the previously mentioned TV Cultura ${ }^{43}$ and Doc.TV, the participants underlined the presence of other organizations including: Autres Brésils and its festival Brésil en Mouvements (Paris), the Canadian National Film Board, Petrobras - for the most famous documentary filmmakers - and Video nas Aldeias, a training space for indigenous youth ${ }^{44}$. SESC TV plays an important role ${ }^{45}$ as does TV Brasil which, according to them, suffers from under-trained staff. They also cite the sums paid by various authorities of Minas Gerais to be as follows: Rede Minas Gerais Belo Horizonte pays 400 reais (about $61 €$ ) for two films and one year of broadcasting. The State of Minas Gerais supports documentary films to the tune of approximately 100.000 reais (about $15.000 €$ ) and the City of Juiz da Fora grants 30.000 reais per film (about $4.590 €$ ). In general, festivals grant 10.000 reais (i.e., $1500 €$ ) to award-winning films ${ }^{46}$. This is the case of the Tiradentes festival, the Ciné Ope d'Ouro Preto, the International Mostra de Belo Horizonte - which has a national impact ${ }^{47}$. In other regions, the Gramado Festival (Ceara) and Brasilia festival are recognized for their reception of documentary films, the Brasilia festival having a political overtone. The participants also underlined an evolution of the documentary themes and subject matter: from culture in general to music, then the intimate - the lives of people - and a new look at butlers or housekeepers, like in Santiago (João Moreira Salles) or Babas (Consuelo Lins). However, despite some good initiatives, they confirm that it is difficult to make a living from documentary alone.

And this is what our interviewees attest, with some exceptions. Most have set up their own production houses, which allows them both to edit their own films and to produce work by other creators. Others work as teachers, consultants, or screenwriters for various clients.

Marilia Rocha regrets the difficulty of working in Minas Gerais, despite contributions from the State. To overcome this problem, seventeen years ago, she participated in the creation of A Teia (the web), in Belo Horizonte, with the idea of aesthetic convergences, and shared promotion and premises. Today, the idea is rather that everyone go their own way, she emphasizes. There is public and private support (Renault), a Filminas prize. The City of Belo Horizonte offers financial assistance 
and there is also the Centro de Referência Audiovisual (CRAV), espaço da Fundação Municipal de Cultura de Belo Horizonte. Petrobras finances via the Rouanet law. TV Cultura has played an excellent role for 5/6 years. But funds are never adequate. In 2014, a group of 500 people from Pernambuco, Rio, Bahia, and São Paulo signed a text on this subject. Forum doc - forumdoc.bh.18, is a well-known Festival of documentary and ethnographic films in Belo Horizonte during the month of November. The Tiradentes Film Festival welcomes young independent directors. The Mostra de cine de Ouro Preto is dedicated to education and archives. "Independent production is very separate from the commercial world (even for experimental fiction films)", she emphasizes. One of the major problems is the lack of money for distribution. The film clubs are one of the players - but not very fortunate. There are also the SESC and Banco do Brasil centers which are promoting dissemination strategies. The problem in Minas Gerais is the lack of technical resources. It is complicated and expensive to call on technicians, all based in Rio or São Paulo. Marilia Rocha points out the international possibilities of documentary support: Tribeca Film Institute ${ }^{48}$, Hubert Bals Fund of the Rotterdam Film Festival (Netherlands) ${ }^{49}$ and Ibermedia (more difficult to access, she said) ${ }^{50}$.

As for Marcos Pimentel, who also resides in Minas Gerais, he has directed one film per year since 1998. Directed in 2013 his first feature film called Sopro (Breath), was presented at Visions du Réel in Switzerland and will be broadcast in November 2021, at the Festival des Trois Continents, in Nantes (France). His films have been screened at the Gramado, in São Paulo, and the Ceara and Biarritz Latin America festivals in October 2013. According to Marcos Pimentel, certain festivals are key for achieving recognition, which is the case for É Tudo Verdade, which he describes as an international showcase. A poiera eo Viento (Dust and Wind) was presented there in 2011, as well as in Biarritz in 2012. That film was also promoted in Los Angeles Hollywood's Brasilia, in Montreal, in Havana, in Guadalaraja (Mexico), in Bolivia, at the Cinéma du réel (Paris) in Tampere and in Japan. In 2013, he received support from ICTV - Cuba - to apply for the Ibermedia fund. The Brasilia festival has since opened up more space for the documentary genre, creating a new category in its favor. The first prize amounts to 250.000 reais (about $38.000 €$ ) for fiction and 80.000 reais for documentaries (about $12.000 €$ ).

As of 2014, Marcos Pimentel along with Gabriela Altaf made a re-creation, of a television series called Diarios sobre o Corpo, which addresses the experiences of characters who suffer from not meeting society's beauty standards. The first episode premiered on TV Cultura at 00:30, after which the series aired on 220 other public TV stations, such as TV Brasil, Rede Minas de Televisão and all educational, cultural, university and community channels in the country.

"What I do know is that it was extremely pleasant to create content for all public TV stations in the country. The opening hours are horrible, the signal from these channels is never so clean, the audience is low, but these stations are an incredible space to generate reflections in the public that we don't find on commercial television channels ${ }^{51 . "}$

For Mariana Ferraz Musse, the calls for proposals are pre-empted by people who are established within the network, which, for a young director is very difficult to break into. Ditto for festivals - in 
fact, Mariana Ferraz Musse made a film in Ouro Preto, which was not even shown by their own festival. On the other hand, it was presented in an Amazonian festival. Access to festivals is uncertain and unpredictable. "The documentary is 'trendy' but still not considered a movie," she insists. (...) The public sees the documentary as a report. After making four documentaries that she describes as "poetic", and considering herself as a "video artist ", Mariana Ferraz Musse values research more than directing. "The system lacks renewal, we feel a certain discouragement in the long run." In 2012, she directed Corpos celestes with Juliette Triangular, and in 2015, Jonathan.

"Unfortunately, here, it's impossible to make a living from documentaries. The documentary remains a minor genre," confirms Belisario Franca ${ }^{52}$.

Franca first offered documentary programmes to various broadcasters including Manchete, and TV Tupi, in New York in 1987, and he launched a series on African pop music in 1988. Manu Dibango and Michel Kolpa Kopoul were interested in a program of five, fifty-minute segments. The project coincided with the 100-year celebration since the abolition of slavery ${ }^{53}$. Fela Kuti, and Mori Kanté were his "stars". He filmed in Lagos, Dakar, and Kinshasa. He obtained some funding through the Rouanet law. He devoted four fifty-minute segments to Caribbean dance (Trinidad, Haiti), with the support of TV Cultura. A private investor was involved in the financial arrangement.

In 1997, Franca opened Giros, a production company that employed a team of two to fifteen people, that combined both musical and lighter productions. The Giros team works on ten projects at the same time, for which Belisario Franca is the artistic director. Every two years or so, he undertakes his own personal project. The team consists of around ten directors.

Belisario Franca produced fifteen programs with Gilberto Gil, 142 rhythms from Brazil, for MTV Brazil. This film was presented at É Tudo Verdade. He also produced a series on religions, Catholicism and violence (twelve programs). He successfully completed Amazonia eterna in 2011. With these documentary series, he notably obtained the Lusophony Prize (IDA) and they were broadcast by TV Brasil.

It took him four years to prepare Menino 23 which was shown theatrically in Rio ${ }^{54}$. Various sources of funding had to be assembled - Multirio acting as a broadcaster ${ }^{55}$; he also counted with the Audiovisual Sectorial Fund (FSA), Petrobras, BNDES and Riofilme which were the main supports along with Discovery and Canal Brazil. A mining company, Vale, intervened thanks to the audiovisual law.

In 1994, back in Brazil, Sergio Bloch won the first prize for a short film at Riofilme. What interested him was making a series about the world of those who roam the city - on foot or by bicycle - for their work. He devoted two films to them, Olha da rua and Tudos a rodas in 2004, an audiovisual accompaniment for all those who, in the cities, carry their goods on a man's back or by bicycle or moped. The prototype was declined in Latin America, under the title Sobre ruedas, with thirteen twenty-six-minute episodes, a series edited with the support of Ibermedia and Canal Futura $^{56}$. He also collaborated with Video nas Aldeias, as a trainer and event coordinator, the idea being that indigenous youth can make their own films. 
Lucia Murat made her first film in Nicaragua (1978), a medium-length documentary which was only completed in 1984. She wanted to meet people of her own generation in Latin America. She was part of the Paissandu generation ${ }^{57}$, very influenced by New Wave. "Cinema and life were strongly intertwined " she underlined. Que bom te ver viva (1989) mixes documentary and fiction, which was rare at the time. She did journalism, because for her, journalism and documentary are very close. In her fiction-documentary films, Lucia Murat constantly comes and goes. It was only from 2004-2006 that she could make a living from her work as a filmmaker. She worked for television, making reports and commercials.

"It's also only fifteen years ago that there has been a policy for sustainable production in Brazil. Young people are not aware of these developments" she stressed in 2016.

She directed Entre os actos - inspired by Simone de Beauvoir - with the support of the FSA (Audiovisual Sectorial Fund) and Petrobras, in co-production with France. And Uma longe viagem in 2011 - a film which also focused on memory. Her films have been distributed in Portugal, Chile, Argentina, and France.

After his audiovisual work for the trade union movement, Joel Zito Araujo directed a short film in 1991-1992, titled Retrato em preto e branco. His first public work, this film was shown in France and New York city (purchased by the Library of Congress), and he received criticism in the press in both Brazil and the United States. In 2000, he directed the film, A negação do Brasil (notably with Ruth de Souzou), about the role of blacks on television. This documentary feature won first prize at É Tudo Verdade and it was screened at many festivals.

In addition to his films, Zito is a curator for festivals like Encontro de cine negro in Rio (during the month of November), a consultant, and a jury member for calls for projects. He is also a teacher and course coordinator at Green Cap, Dakar, in Mozambique and he is a member of the Pan African Cinema Federation (FEPASI). He manages to make a living from his various activities. In Brazil, he has benefited from various supports including The Cinema Sectorial Fund, Globo Filmes, and Petrobras.

In 2016, he was very worried about possible political developments in Brazil:

"With Dilma Roussef, it was austerity and a worrying misunderstanding of trade union movements and civil society. (...) With Michel Temer, culture has become the enemy ${ }^{58 . "}$

While Joel Zito Araujo was a member of the civil society council of TV Brasil, Michel Temer hastened to remove the council.

Helena Solberg made her first film in 1967 that dealt with the issue of young women in her community. None wanted to appear on screen, so she had to construct surrogate images. Her film was distributed at the Maison de France and at the Locarno festival. She was a script writer for Cinema Novo, but at the time, she disapproved of the lack of consideration of women's issues. In 
the 70s, she took up residence in the United States for about 30 years, where she directed several productions, among them: From the Ashes: Nicaragua Today (1982), which won a News \& Documentary Emmy Award. From the 80s, she began to direct a series of documentaries for international TV channels such as HBO, PBS, Channel 4, Radio and Television of Portugal, National Geographic Channel, among others. Her work has been shown in many festivals: Center Pompidou (the Cinéma du Réel), Biarritz, Lyon, Toulouse, Sunny Side of the Doc (Marseille). In the USA she would come up with a topic and get paid to complete it by PBS, among others, she underlines. She returned to Brazil every year but 1995 was the date of her lasting return. Bananas is my business, a film about Carmen Miranda, was very well received and allowed her to mark her comeback ${ }^{59}$. She made Vida da meninha, based on the diary of a young girl who wrote aged 13 to 15 . The book has been translated into French and English. The film was shot in Diamantinas, the hometown of the girl. She participated in a program in a favela with choreographer Evaldo Mare (on Indian dance). She came back ten years later to film the same people: $A$ alma da gente. To do this, she responded to a call for proposals.

Financially, she can survive on her productions, but nothing more. The problem in the film and documentary economy in particular, is that the distributor does not lend funds and it takes two to three years between the making of each film.

For Silvio Tendler, traditional Brazilian sources of funding do not work: he has never cooperated with Embrafilme, and according to him, Ancine is not that efficient. As a result, he created his own company, Caliban Produções Cinematográficas, through which he works for the whole of Brazil. He "has to go where the money is. ${ }^{60}$ "

His films were very well received in Cuba, Miami, the Brazilian Film Festival in Paris, MOMA (New York), Berlin, Mexico, and Argentina. He feels no obligation to be tied to a single television network. TV Brasil supported four or five of his projects and TV Cultura has helped one or two. In addition, he made special 50-minute versions for TV Cultura and he shot a miniseries, Anos rebeldes For TV Globo, ${ }^{61}$.

O veneno esta na Mesa (the poison is served) is a film about ecology, released in 2011, which attracted more than 50,700 spectators. Silvio Tendler has made a living from his work for a long time. He is also President of the Brasilia Film Festival, and as such, he helped save the 2019 edition of the festival, delayed due to the Petrobras withdrawal.

Susanna Lira focuses on themes like human rights, politics, and violence. She is known for documentaries like Mataram Nossos Filhos (2016), Legítima Defesa (2017), Torre das Donzelas (2018) and for creating and directing the series Rotas do Ódio (2018), produced by Universal Channel. Susanna Lira won one of the first prizes at the Rio International Festival in 2009, for Positivas. Europe is very important to her. Torre Das Donzelas was broadcast in France. She won several awards, including Best Documentary and Best Directing in the important Rio Festival in 2018, for her film Torre das Donzelas, in which she interviews women who were imprisoned and tortured in the Brazilian military dictatorship - Dilma Roussef among them - while asking them to re-occupy the reconstituted space of their prison. She works a lot for festivals. "On television, we don't know who is watching". Tiradentes shows independent films. The Brasilia festival pays 15.000 reais (more 
or less $2300 €)$. They are small groups with meager resources. The Ford Foundation has few resources. There is also the Rouanet law - and the audiovisual law. In 2018, Michel Temer closed the calls for proposals to companies. Ancine had not been in operation for eight months. Anyway, Susanna Lira believes that "the resources available are very limited for projects with high budgets". Until now, she makes a living from her work as a documentary maker ${ }^{62}$.

Eryk Rocha made his first film in 2002: Rocha que voa, from the archives of the Instituto Cubano del Arte e Industria Cinematográficos. The film was selected in the Locarno, Venice, Montreal, and Havana festivals, and awarded as the best Latin American feature film at Cinesul, in Rio de Janeiro in 2002. He also received the award for best Brazilian documentary at the Festival É Tudo Verdade of 2002, from the Associação Brasileira de Documentaristas (ABD).

Eryk Rocha worked for TV Canal Brasil and TV SESC with ten directors from Latin America. The theme was education, and it was very "artisanal". He was invited to a few conferences and won prizes at É Tudo Verdade and in Latin America. He returned in 2000 and made two films. His second feature, Intervalo Clandestino (2006), records the presence of the 2002 presidential campaign on TV and on the streets in Rio de Janeiro: "It was about politics as seen by people who are not politicians, the polyphonic imagination of peripheral people." The film was awarded by Petrobras: a circuit of diffusion in all the country, debates of three hours. Pachamama (2008) analyzes the traces of the Inca civilization in the Peruvian Amazon in the 21st century. It's a road movie through Brazil, Peru, Bolivia... In cooperation with an archaeologist and a historian. (...) The point of convergence is the multitude and the uniqueness of Latin America. The film had a good reception. "Bolivia dreamed of reinventing politics from its ancestral past. The main theme of this film is the relationship with the world". Then he made Transeuntes, a film on silence, devoted to the individual $(2010)^{63}$.

For Christina Grumbach, film festivals are interesting in order to meet directors: to dialogue, to see the work of others. But it's more marginal to meet the public. O morro da Conceição spent three months in the theater, with 6000 viewers. Then, she directed As Cartas Psicografadas por Chico Xavier (2010). However, festivals are not a priority, she says.

"You have to understand that the money invested in the film is the initial value of it. If there's more money, it's for me. I sold on cable TV, Netflix (As Cartas Psicografadas por Chico Xavier). 2.500 reais (i.e., $382 €$ ), that is, after commission from the distributor, 1.500 reais (i.e., $230 €$ ). I was able to survive by making films. It's already a miracle."

When we met, $100 \%$ of resources were spent on survival, she said.

"When I didn't have kids, I worked on my plans. After that, it was impossible. I won a call for proposals, and I will be able to live in October, November and December 2016. $10 \%$ of my time is free for my films. ${ }^{64 \prime \prime}$ 
Deborah Herszenhut entered the market through her freelance work. She was a producer of festivals, and exhibitions, where she worked with art and advertising. Then she was assistant director for the documentary. She also worked as a researcher at the university, in the field of anthropology. She did music videos and casting.

She opened several fronts, including a social education project for Video nas aldeias, which was a documentary on Guaranis, with a linguist, a topic on which she was preparing a series. She also worked as a consultant for various organizations. Brazilian legislation obliges companies that produce major works to make an inventory of the regions they want to go, hence they need audiovisual documentation.

Public calls for proposals are a complicated world, she said.

\begin{abstract}
"A mature CV is better than all the good ideas of young talent. Cooptation is very strong in the audiovisual milieu. To write a project, it takes two months. The other solution is to be a technician. But I feel more comfortable in the academic world (...) Experience in documentary films, knowledge of the third sector and anthropology, these are my three strengths and I intend to make them flourish, while connecting films with anthropology ${ }^{65} . "$
\end{abstract}

As for Emilio Domingos, he designs projects without support, while working as a researcher for TV Globo. "I cannot live on documentaries. I work for the future new Museum of Image and Sound." He also addressed environmental issues, notably with an order from a specialist company, Hydroelectrica. At the end of the 1990s, calls for documentaries increased because television needed programs. There was also more money: 500 prepaid DVDs on the Internet, 2000 DVDs planned, 55 reais per DVD $(8,40 €)$. "The Rouanet Law, the calls for proposals, are worse than the vestibular $66 "$ ", he was indignant. According to Domingos, the system favors those who write the best. The government wants Brazilian cinema to be known around the world. There is some sort of formatting. Language matters more than the subject.

"I see the possibility of interviewing groups and individuals, to have situations known, to tell different stories. I am not a political filmmaker, I am looking for subjects that interest me. I work with various producers."

As a director, Emilio Domingos made the following films: $A$ Batalha do Passinho ${ }^{67}$, winner of the New Directions Show at the Rio Festival (2012), Deixa na Régua, winner of the Special Jury Prize at the Rio Film Festival (2016), Favela é Moda, winner of the Best Documentary Feature Film of Popular Vote at the Rio Film Festival (2019). Also, A batalha du Passinho was broadcast in Belo Horizonte, Bahia, Tiradentes and in Paris (Maison de l'Amérique latine).

In terms of distribution, for Joel Pizzini, there is Cine Ceara, Doc em Lisboa, the Amsterdam and Rome festivals. He rented a space and won calls for projects from Itaú cultural ${ }^{68}$. Canal Brasil, Petrobras and Riofilme all provided their support. The technical center of the Ministry of Culture can help edit DVDs. It is a politics of memory. Joel Pizzini was the curator for the restoration of 
Glauber Rocha's work. He teaches in Curitiba and at the Rio PUC. He is part of the selection committee of the Brasilia Film Festival. He has won numerous awards for his works: Bahia Days of International Cinema for Enigma de um Dia (1996) and in Gramado, Special Jury Prize at the Brasilia Film Festival, Best Documentary Prize at the Rio de Janeiro Film Festival for 500 almas, Golden Bear for the short film at the Berlinale for Mar de Fogo in 2014. His feature-length documentary dedicated to Ney Matogrosso, Olho Nu (2014) was presented at the 43rd São Paolo International Film Mostra.

Actor, screenwriter and director, José Joffily founded the production company Coevos Filmes in 1981, with which he started to produce his audiovisual projects. Although he is mainly a creator of works in fiction, Joffily also made inroads in the documentary genre, as in $O$ chamado de Deus (2001) voted best documentary at the Brasilia film festival and Vocacão do poder with Eduardo Escorel in $2005^{69} 70$.

Karla Holanda considers the documentary market to be "very closed". In principle, on pay-TV, three and a half hours should be devoted to independent productions. But, she wonders, who can afford to watch pay TV? Anyway, television pays badly. Karla Holanda benefited from Petrobras' call for proposals for her fifteenth film Kátia which won several distinctions in 2012. The production took place in Piauí about Kátia Tapety, the first transvestite in Brazil to be elected to a political office. The film debuted at the 45th Brasilia and was selected at the 36th São Paulo International Film Festival and the Brasilia Festival, in addition to receiving the awards for Best Film, Photography and Editing at VI For Rainbow (Fortaleza). It also received a prize in Mix Brasil (São Paulo).

"I think that in Kátia Tapety's daily life she works for human rights and for the tolerance that I call "silent", because she does not use any elaborate speech, nor does she weave theory. She lives as she believes she should live, this is her biggest flag", Karla Holanda said. ${ }^{71}$

But would this film have had help from Petrobras in 2019? A Folha de São Paulo on June 13, 2019, reveals that several films and festivals have not received their endowments promised by the company: A torre das donzelas (Suzanna Lira, a promise of 100.,000 reais, about 15,278 €) Meio Irmão by Eliane Coster (200,000 reais promised, about 30,557€), Bixa Travesty by Claudia Priscilla and Kiko Goifman"2. All delicate subjects for the new government. Jair Bolsonaro declared: "Não é censura, é respeito a população brasileira." ("It's not censorship, it's respect for the Brazilian population.") And what about the festivals deprived of their sponsorships? The São Paulo International Film Exhibition, supported since 2000 by Petrobras, the Rio de Janeiro international film festival, which saw its budget evaporate and must reduce its programming, as well as the Brasilia film festival, fortunately supported by the secretariat of the Culture and Creative Economy of the Brasilia District?

Before this earthquake, Karla Holanda was particularly interested in Doc.TV, a federal attempt from 2003 to 2010, to decentralize the Brazilian production of documentary films and to establish links between public television and independent production, "common em varied paises, but, by 
deceased, evitada a todo custom no Brasil" ("common in varied countries, but, by deceased, avoided all custom in Brazil").TV Brasil's audience share is only 0.5\%, however TV Cultura broadcast 35 films, or $20 \%$ of its programming, as part of the third edition of Doc.TV. "The audience isn't significant, but the local impact is." Over the years of the program, the sum granted for the production of documentaries has been 100,000 (i.e., 15,278 $€$ ) and then 110,000 reais (about 16,800 $€$ ). The television network that broadcasts receives 27 other programs (and in fact twice as much, according to Karla Holanda). Viviane Louise, one of the program's winners for her film Café com pão, manteiga não, acknowledges that Doc.TV has enabled her to mature her desire for directing. Indeed, the program was conceived as a series of poles in each Brazilian state, with local coordination but also tutors, and filmmakers themselves. This set was very suitable for developing the scenarios and understanding how the directors saw their initiatives.

Karla Holanda describes Doc.TV's initiative as a "unique experience" with 131 documentaries produced in the country's 27 federative units ${ }^{74}$. The program matured in 2002, with the National Audiovisual Seminar coordinated by filmmaker Orlando Senna.

For example, the film Raimundo, a quebradeira by Marcelo Silva was sold to the 27 units of the SESC, for a sum of 1,000 reais (more or less $152 €$ ) per copy (shared between author, producer, local program and MinC funds to finance new productions).

The challenge of meeting the public: dissemination / distribution / marketing

"What matters", Marcos Pimentel insists,

"is reaching the public. In $2009,6 \%$ of the population had access to pay cinema. There was no advertisement for the documentary offering. Exhibitors don't give a film time to exist. ${ }^{75 \prime \prime}$

Duy blow one could read in Portal Impresa of June 1, 2009:

"The DOCTV Program opens on June 5 (Friday), at 10:40 pm, on TV Cultura, its fourth series of unpublished documentaries. In this edition, there are 55 titles, all coproduced through the Brazilian Documentary Program to Promote Production and Broadcasting. For one year, weekly documentaries made throughout Brazil will be shown based on the association between local public TVs and independent producers. In other states, the documentaries will air on the TV programming grids and alternative circuits of the public institutions participating in the program. (...) The Program is carried out by the Audiovisual Secretariat of the Ministry of Culture, ABEPEC - Brazilian Association of Public Educational and Cultural Broadcasters, TV Cultura - Fundação Padre Anchieta, and TV Brasil - Empresa Brasil de Comunicação, with the support of ABD Nacional - Brazilian Association of Documentarians and Short Filmmakers." 
In 2011, the program was suspended by the government of Dilma Roussef. Only Doc.TV Latin America and Doc.TV CPLP still operate:

"Doctv is a programme to support the production and broadcasting of Latin American documentaries. It is an initiative from Conferencia de Autoridades Cinematográficas de Iberoamérica - $\mathrm{CACl}$ - and the Fundación del Nuevo Cine Latinoamericano and its aim is to call for applications in the countries that belong to the programme to select projects for documentaries. Doctv, which was inspired in a previous experience in Brazil, is a pioneer model for the coproduction, television broadcasting and distribution of documentaries, systematized with the concept of a network operation. The 19th $\mathrm{CACl}$ Meeting was held in the city of Antigua in the Republic of Guatemala on November, 16, 2010. It was decided to proceed with a third edition of Doctv, and Instituto del Cine y Audiovisual del Uruguay - ICAU - was designated as the headquarters of the Management Unit in charge of executing the programme. In this edition there are at least 14 documentaries." (Source: Doctv Latinoamérica Fund Executive, 2011).

The idea of a Latin American cultural transfer is interesting, as well as the relay taken by a number of countries. Doc.TV also exists for the Community of Portuguese Speaking Countries, as evidenced by these few lines taken from the Doc.TV CPLP program:

"The CPLP Audiovisual Program has a budget of approximately three million euros and contributes to cultural exchange, to increase mutual knowledge and to the implementation of integrated public policies to promote the production and broadcasting of audiovisual content in the member states CPLP ${ }^{76}$." (Source: CPLP, 2016.)

Karla Holanda considers these two initiatives as models of "cultural diplomacy"77.

The fact remains that Doc.TV Brazil had to close its doors while the program was at its mature stage, with improvements in each edition. The filmmaker and professor Eduardo Escorel, one of the tutors of the program, told Karla Holanda in 2012:

"We sin a lot in Brazil by discontinuing projects. We change the Culture Secretariat and the project ends because it came from another. I think the experience was too brief to assess its effects with any more objectivity" ${ }^{78}$.

Regarding distribution, Lucia Murat believes that:

"even if public policy has done things for cinema and audiovisual, it has not touched the monopoly of film and audiovisual distribution. VOD poses a lot of problems because it does not generate any revenue. In addition, author's cinema will no longer be distributed in theaters. ${ }^{79}$ " 
According to Deborah Herszenhut, Brazilian festivals should function as showcases for national and international distribution. However, this is rarely the case, with the exception of É Tudo Verdade. Culture points facilitate circulation ${ }^{80}$. But they ask to give up its material free of charge. Films are not supported for distribution.

Emilio Domingos goes through festivals, and film clubs as well as culture points, to disseminate his work.

Yet Eryk Rocha sees cinema as a contribution to the construction of memory. The problem of distribution is global. For him, "there is no cinema without public policy". There are new popular digital circuits, he observed. Ponto Cine Guadalupe networks 80 venues with tickets at 4 reais $(0,61$ $€)$. Street vendors sell the ticket for 5 reais $(0,76 €)^{81}$. $90 \%$ of municipalities do not have a theatre. They broadcast for 200,000 people against 200 customers for a traditional venue.

The funds have evolved and films are shown internationally. It's the number of tickets sold that counts. And the film clubs, international and innovation are not included.

According to Eryk Rocha, the problem of distribution is global. "We have to reinvent the social space of cinema. The market is occupied by American cinema. We need alternatives."

Helena Solberg regrets that distributors are withholding funds. It takes two to three years between the making of each film. "Author films are the most difficult to produce. In fact, the market for these films does not exist". This is what she explains to her PUC students. "Technology is changing very quickly. Young people no longer go to the cinema."

For Joel Zito Araujo, the Minister of Culture Juca Ferreira already wanted to reform the Rouanet law. If the sponsoring companies pay only $80 \%$ of the taxes, they must donate $20 \%$. But often, they manage to get some of the money back from their sponsorship. The corruption is enormous. In addition, companies choose what is the most spectacular: mainstream and southeast of the country only. We must add to these observations the fact that private funds only represent $10 \%$ of financing requirements.

According to him, CUFA has energized things, putting the periphery at the center as a source of culture (and not just by facilitating access). The Central Única das Favelas (CUFA) is a Brazilian organization recognized nationally and internationally for 20 years of social work in slum territories and periphery through cultural, artistic and sports projects. (Source: CUFA website, https://www.sympla.com.br/cufa).

There is also Cooperiferia, an organization present in the favelas, in particular through its writers and poets. They broadcast Joel Zito Araujo's films.

Points of culture are useful for Mariana Ferraz Musse, but it's impossible to make a living out of it. Calls for projects are useless for distribution. Movie theaters don't want to host documentaries because the audience is too small.

Coordinator of the Content and Quality Unit of TV Cultura from 2007 to 2010, Gabriel Priolli confirms:

"Viewers only accept journalistic documentaries, such as Globo Reporter, in which the narrative is conducted by a presenter and the simple motorbike enjoyment, muti say, enzo requires mental effort. They also accept, albeit less, documentaries 
with narration on off, like Discovery Channel, which are also easy to assimilate." (Gabriel Priolli, 2011, in an interview by Karla Holanda) ${ }^{82}$.

On this subject, Karla Holanda and Joel Pizzini denounce the production of "commercial documentaries" distributed in theaters - in particular centered on famous figures - and in which the director is "instrumentalized", according to Joel Pizzini's expression: films on Vinicius de Morais, Talking Heads, Woody Allen ...

One of the problems with Doc.TV has precisely been distribution and return on investment. Eduardo Escorel regrets the program's lack of a long-term vision:

"Well, doing a three or four year experiment, where does that take us? (...) You offer an opportunity, the person makes a film, the film is interesting, and this person is again faced with the same difficulty they had, before working for DocTV. ${ }^{83 \prime}$

In addition, Doc.TV's efforts to export the films were called into question by its discontinued presence in television markets. And this is due to lack of means.

Directors working for Doc.TV cannot sell a single DVD or post their documentary on the Internet. The natural way would be to free all the economic rights for the authors, for the producers, according to Paulo Alcoforado (interviewed by Karla Holanda in 2012) ${ }^{84}$.

Karla Holanda underlines:

"[...] The commercialization of national DocTVs to other stations and in other windows is the main negative point of the Program highlighted by the directors. The fact is that the results achieved were very timid, restricted to isolated sales and to a few commercialized DVDs. (...) However, in order to work, it would be necessary for the MinC (ministry of Culture), which holds most of the rights to the films, to find mechanisms for continuing the process, even when management changes. The same goes for public TV, a minority co-producer, but with a greater structure to find buyers for its products."

There remains the problem of piracy, which is significant in Brazil. To this question, Silvio Tendler responds with humor that may not be appreciated by everyone: "It's the Americans who always want money. It's an honour to be hacked. We are in good company! 85 "

\section{Conclusion}

The directors we have met all stress the level of difficulty in producing their films, marketing them and of benefiting from a return on investment which would allow them to continue their work. Moreover, in public agencies, management remains a challenge. As an example, in 2011, Ancine succeeded in convincing the public authorities to strengthen support for the film industry, with the creation of a new tax on television services (which particularly affects telephone and cable television operators). Thus, in 2012, CONDECINE ${ }^{86}$ collected 16 times higher tax than that of the year 2011, i.e. 
725,332,169 reais (about 106 million €). However, Ancine only used 48 million reais (about 7.3 millions $€$ ) from CONDECINE in 2012, which means at that time, the Agency had funds far exceeding its operational capacity ${ }^{87}$.

In addition, unlike the French system among others, at the federal level there is very little automatic support for production and distribution. The Audiovisual Sectorial Fund of the Federation has a marketing line for Brazilian feature-length works (action line D), but only for distribution in cinemas in the country, and for works "in the finalization phase or completed" and awarded at festivals (Source: Ancine, FSA, ministry of Citizenship, 2020).

"Today, automatic aid represents only $3.6 \%$ of the aid granted. While it is obviously not a question of renouncing the selective aid which ensures the diversity of national production and ideas, the establishment of automatic aid would make it possible to lighten administrative procedures and shorten the financing periods of a film ${ }^{88}$, to interest producers in the success of the film, to promote the emergence of a greater number of films with strong commercial potential, Emmanuel Rufi suggests."

Among all the data provided by Ancine, three figures caught our attention: from 2004 to 2008, the cinema audience for Brazilian films went from 16,410,957 to 9,143,052. As for foreign films, they were screened in front of 80,322,112 people in 2008. (Source: Ancine, 2009). This also means alternative sources need to be put in place throughout the cinema and audiovisual value chain. Even though Canal Brasil broadcasts a majority of Brazilian works in terms of airtime, its audience remains low. Likewise for TV Cultura, despite the promotional efforts made during the four editions of Doc.TV. And above all, the revenue increases are too low.

In addition, recent political changes in the country make the prospect of a Brazil open to all directions and to the multiplicity of social and intimate adventures even more distant. At the same time, the festivals of Cannes, Berlin, Rotterdam, Gothenburg and others have mobilized since 2019 to welcome and reward quality Brazilian films, and which have won an international audience, whether it is fiction or documentary. Paradoxically, the confinement in which the government of Jair Bolsonaro intends to lock up his country, increases interest in Brazil and its stories, as does the distribution on certain platforms including Netflix, such as Democracia em vertigem by Petra Costa ${ }^{89}$, nominated for the 2020 Oscars, even if another Netflix jewel won the day: American Factory by Stephen Bognar and Julia Reichart ${ }^{90}$.

The international relays handled by Doc.TV Latin America and Doc.TV LPLP demonstrate the exemplary nature of certain Brazilian cultural initiatives, just as how the Culture Points have been implemented in Latin America and Europe. These breakthroughs in the glass ceiling of a Brazilian system dominated by private interests, herald new opportunities for Brazilian designers. But they remain cautious in the presentation of themselves: most of the documentary filmmakers encountered present themselves as filmmakers, either because the documentary is not their only horizon (Marilia Rocha), or because the public does not understand the term and risks confusing "documentarista" with "documentalista", as Christina Grumbach jokingly puts it. With the film 
Samba which was the starting point for increased visibility, Theresa Jessorum began to "see herself as a documentary filmmaker". Susanna Lira is categorical on the question: "It is an important political act to claim to be a documentary filmmaker. We work from reality." Karla Holanda considers herself a director working like a craftsman. Sergio Bloch doesn't see himself as a filmmaker, but this is how he describes himself, "because people don't understand what a documentary filmmaker is." As for Lucia Murat, given her history, she sees herself more as "a survivor "91.

${ }^{1}$ See Erving Goffman (1959). The Presentation of Self in Everyday Life, Doubleday \& Company: Garden City, N.Y., and Howard Saul Becker, (1982) Arts Worlds, University of California Press: Berkeley.

${ }^{2}$ Three directors mainly lived in Minas Gerais, fourteen mainly lived in the State of Rio de Janeiro, at the time of the interviews.

${ }^{3}$ In 2019, the Bolsonaro government canceled calls for proposals for LGBT works.

${ }^{4}$ Since 2007, the author has benefited from contacts in Rio de Janeiro, São Paulo, Belo Horizonte, as guest professor or speaker at the Federal University of Rio de Janeiro, the Federal University of Juiz da Fora and the PUC of Belo Horizonte.

${ }^{5}$ (2004) Summus Editorial: São Paulo.

${ }^{6}$ And by a then illegal contribution from the American company, Time Life.

${ }^{7}$ Interviews with professors Christina Ferraz Musse and Alfredo Suppia (Federal University of Juiz da Fora), as well as with producer Cristiano Rodriguez, May 31 / June 1, 2012, Juiz da Fora, Minas Gerais.

8 Joel Zito Araujo, "O tenso enegrecimento do cinema brasileiro nos últimos 30 anos", in Latin America Cinemas n²6/2018.

${ }_{9}^{9}$ Master's thesis in communication from the Federal University of Juiz da Fora, Margens nada plácidas: documentário, entrevista, alteridade e identidades, 2011, under the leadership of Professor Dr. Aluizio Trinta (pp. 32-33).

${ }^{10}$ Tropicalism encompasses theater, poetry and music at the same time. Its goal: to combine the avant-garde with popular tradition to liberate and make the Brazil of tomorrow sing. Its instigators: young musicians who have since become legends, far beyond the borders of their country, like the Os Mutantes clique, Gal Costa, Tom Zé, Chico Buarque, but especially the fathers of the movement, Gaetano Veloso and Gilberto Gil. (Source: La Libre, "Tropicàlia or the Brazilian Revolution", July 4, 2018.

${ }^{11}$ Suely Rolnik (2013) "La place de Vincennes dans ma vie" in France-Brésil, Échanges intellectuels et artistiques. Repères historiques et prospectifs (Anne-Marie Autissier, Geraldo Nunes, Ridha Ennafaa eds.) Le Fil d'Ariane, Paris 8 Institute of European Studies: Saint-Denis, pp. 41-46. Proceedings of the seminar organized in Rio de Janeiro (UFRJ) and dedicated to the 40th anniversary of Paris 8 within the framework of France Year in Brazil.

${ }^{12}$ Aline Carvalho (2012), "The effect of the 'counter-culture' on Brazilian policies", in Culture Europe International, Special Brazil.

${ }^{13}$ Documentary account of the life of João Pedro Teixeira, peasant leader of the State of Paraíba, assassinated in 1962. The film was interrupted in 1964, due to the military coup, and was not restarted until 17 years later, with the testimonials from people who took part in the first shoot. The film won ten awards at festivals in Rio, Caxambu (Minas Gerais), Havana, Berlin and Cannes (Source: Cannes festival website).

${ }^{14}$ Interview of September 17, 2016, Rio de Janeiro. 
${ }^{15}$ Mariana Ferraz Musse, Opus cit., page 9.

16 Ismail Xavier (2015), «Des façons d'écouter dans un média visuel. Le mouvement du documentaire au Brésil », in Agone 2015/2, n57, pp. 65-90.

${ }^{17}$ www.filmeb.com.br

18 Interview of July 27, 2007, São Paulo. It's All True (É tudo verdade) is the title of an unfinished Orson Welles feature film comprising three stories about Latin America.

19 Fabio Earp and Helena Sroulevich (2008). "Consumer behavior of cultural products and entertainment combos", in Victor A. Melo (ed.), Leisure: historical aspects, contemporary configurations, Editora Alínea: São Paulo. See also Helena Sroulevich and Fabio Earp (2019), "The cinema market in Brazil", in Cultural policies: Reflections and actions, Rui Barbosa's house, Itaú cultural: Rio de Janeiro.

${ }^{20} 2007$ interview, Ibidem.

${ }^{21}$ Apart from Silvio Tendler's films, Condor by Roberto Mader (2002) is a masterpiece about secret 'anti-subversive' coordinated operations in the southern code.

22 Interview of August 10, 2014, Rio de Janeiro.

${ }^{23}$ See Consuelo Lins (2004), O documentário de Eduardo Coutinho, Televisão, cinema e vídeo, ebook (ePub). See also Gustavo Coura Guimarães (2014), Eduardo Coutinho et la recréation du documentaire brésilien, Éditions Universitaires Européennes: Sarrëbruk. As well, Helena Oliveira Teixeira de Carvalho (October 2017) « Santo Forte : um diálogo entre Eduardo Coutinho e a historia oral », in XXI Socine, O estado da crítica, Paraíba Federal University, pp. 357-363.

${ }^{24}$ Karla Holanda (2017), DOCTV: a producão ndependente na televisão, Novas Edições

Académicas: Beau-Bassin, Mauritius, page 43.

${ }^{25}$ Interview of September 2, 2016, Rio de Janeiro.

${ }^{26}$ Phone interview on August, 8, 2013.

${ }^{27}$ Interview of August 8, 2014, Rio de Janeiro.

${ }^{28}$ Interview of September 2, 2013, Rio de Janeiro.

${ }^{29}$ Interview of August 12, 2014, Rio de Janeiro. Under the inspiration of Jean Rouch, the Ateliers Varan were created in Paris to teach documentaries, in the form of a collective pedagogy centered on practice. The Ateliers Varan have international activities.

${ }^{30}$ Phone interview, August 28, 2013.

${ }^{31}$ Interview of September 17, 2016, Rio de Janeiro.

${ }^{32}$ Interview of September 18, 2016, Rio de Janeiro.

${ }^{33}$ It should be noted that, thanks to his family origins, Eryk Rocha benefited very young from an immersion in the world of cinema: he is the son of filmmaker Glauber Rocha and of Paula Gaitán, a visual artist and filmmaker whose works and films have been internationally released. Eryk Rocha dedicated a film to Cinema Novo, Cinema Novo, in 2016. That film was awarded «Oeil d'or» at Cannes festival in 2016.

${ }^{34}$ Interview of September 9, 2016, Rio de Janeiro.

${ }^{35}$ Interview of August 28, 2008, Rio de Janeiro.

${ }^{36}$ Interview of August 10, 2014, Rio de Janeiro.

${ }^{37}$ Interview of June 6, 2012, Rio de Janeiro.

${ }^{38}$ Interview of August 8, 2014, Belo Horizonte.

${ }^{39}$ Interview of September 5, 2016, Rio de Janeiro. Emilio Domingos studied Anthropology at UFRJ.

${ }^{40}$ Interview of September 14, 2016, Rio de Janeiro.

${ }^{41}$ Interview of October, 1st, 2019, Paris, in the frame of « Brésil en mouvements », Autres Brésils festival. 
${ }^{42}$ See pp. 3-4 in this article. Interview of August 16, 2013, Juiz da Fora.

${ }^{43}$ TV Cultura is a free Brazilian television network headquartered in São Paulo and a part of Fundação Padre Anchieta. It focuses on educational and cultural subjects but also has sports as entertainment options.

${ }^{44}$ Regarding Videa nas aldeias, the editing is done by external contributors. The Indians began to direct their own films. O Mestre e o Divino by Tiago Campos, was presented in 2013 at the 46th Brasilia Film Festival where a documentary category was created. He won the first prize, tied with Exilados do Vulcão by Paula Gaitán. Video nas aldeias is coordinated by Vincent Carelli. 2014 interview with Joel Pizzini, Ibid.

45 "The SESC (Social Service of Commerce) entity in São Paulo arose at the heart of the industrialization process of the late 1940s, from which the bases of an internal consumer market developed, alongside the urbanization reforms underway in various Brazilian federated capitals. The expansion of the internal market then required skilled labor and improved living conditions for workers living in cities, and the initiative was partly taken by entrepreneurs in commerce and industry. (Source: Danilo Santos de Miranda, regional director of the São Paulo SESC, "Culture in the urban context: the experience of the São Paulo SESC", in Culture Europe International, Special Brazil, 2012).

${ }^{46} 2012$ figures. Let us precise that in Brazil, the minimum wage/month is 1039 reais/158,14 $€$ and that in France, it is 1521,22 $€$ (figures of 2020 for Brazil and 2019 for France).

${ }^{47}$ A film festival was also created in Juiz da Fora in 2011, Primeiros planos, dedicated to young directors.

${ }^{48}$ The Tribeca Film Institute (TFI) was a year-round non-profit arts organization founded by Robert De Niro, Jane Rosenthal, and Craig Hatkoff in the wake of September 11, 2001. TFI's mission was to empower filmmakers through grants and professional development and train the media-makers of the future by bringing film into the classroom, developing young audiences for independent film, and promoting career development. TFI suspended its activities in 2020 (Source: www.tribecafilminstitute.org).

${ }^{49}$ The Hubert Bals Fund is a curatorial fund dedicated to supporting filmmakers from Africa, Asia, Latin America, the Middle East and parts of Eastern Europe in every stage of the filmmaking process - from script development to post-production. (source: https://iffr.com/en/hubert-bals-fund).

${ }^{50}$ Created in 1998, Ibermedia is an inter-governmental program to stimulate the co-production of fictional films and documentaries made up of twenty-one countries. Ibermedia's mission is to work towards the creation of an Ibero-American audiovisual space through financial aid and through calls that are open to all independent film producers from the member countries of Latin America, Spain, Portugal and the recently incorporated Italy. In 2020, Ibermedia has opened an application for series. (Source : www.programmaibermedia.com).

${ }^{51}$ Email of September 15, 2014.

522016 Interview, Ibidem.

${ }^{53}$ Michel Kolpa Koupol was a French journalist and DJ specializing in music with international connections. In particular, he established lasting links with Brazilian professionals. He died in 2015.

${ }^{54}$ In homage to the historian Sydney Aguilar, the film is devoted to the "eugenic" experience of a wealthy family near São Paulo, close to the theme of Nazism in the 1930s. Black children were held in one of their haciendas, as test subjects.

${ }^{55}$ Since its creation, on October 18, 1993, MultiRio - Municipal Multimedia Company has been linked to the Municipal Education Secretariat of the City of Rio de Janeiro. Through its digital platform, MultiRio offered more than 7,000 titles. (source: http://multirio.rio.rj.gov.br). 
${ }^{56}$ Canal Futura (Futura Channel), also known as Futura, is a Brazilian-paid educational television channel. It belongs to the Globosat group of channels. Since 2010, it has launched a call for proposals for feature-length documentaries, $\mathrm{O}$ edital Doc. It also manages $\mathrm{O}$ Edital Doc Futura for short films. (Source: www.futura.org.br).

${ }^{57}$ The Cinema Estação Paissandu (or more commonly, Cine Paissandu) was a famous cinema located in the neighborhood of Flamengo, Rio de Janeiro. It is well remembered for having been in the 60s and 70s (the time of dictatorship in Brazil) a center of discussion on nouvelle vague cinema, new and cutting edge European cinema and other subjects (politics, history, culture, arts etc.) and the periodic meeting of moviegoers from its foundation until the closing, even forming the so-called "Paissandu generation". (Source: Wikipedia in portuguese language).

${ }^{58}$ We will remember in particular how the Temer government prevented Kleber Mendonça Filho's film Aquarius from representing Brazil at the Oscars for foreign films. The film crew pointed out the Temer government at the Cannes film festival. "The Brazilian film "Aquarius", nominated for the Palme d'Or at Cannes and showing in Brazil, has become a symbol of resistance to the conservative government of Michel Temer: the screenings end with cries of "Fora Temer!" (Source: Agence France Presse, "Brazil: Aquarius, the film that has become a symbol of resistance to Temer", Sept. 10, 2016).

${ }^{59}$ A singer and a dancer, Carmen Miranda is considered as "the first Brazilian star". There is a small Carmen Miranda museum in Rio (Flamengo) but the future new Museum of Image and Sound will have a whole space dedicated to Carmen Miranda. Helena Solberg participated in the preparation of this space with films. The new museum was due to be opened in 2020.

${ }^{60} 2013$ interview, Ibidem.

${ }^{61}$ Among his many works, one could quote Jango (1984) and Glauber o Filme, Labirinto do Brasil (2003)

622019 Interview, Ibidem.

632013 interview, Ibidem.

${ }^{64} 2016$ interview, Ibidem.

${ }^{65} 2016$ interview, Ibidem.

${ }^{66}$ Difficult entrance exam to enter university. Its elimination was being considered in some universities.

${ }^{67}$ Emerged in the favelas Rio's, the Passinho, exploded in 2008. A new form of dance funk, the Passinho, has been the carioca cultural manifestation more important in the last 10 years. (Source: Osmose Films, osmosefilmes.com.br)

68 Instituto Itaú Cultural is a Brazilian not-for-profit cultural institute owned by Itaú Unibanco. Its goal is to map artistic manifestations and to foster artistic research and production related to all cultural sections.

${ }^{69} 2008$ interview, Ibidem.

${ }^{70}$ Although José Joffily is primarily a fiction director, we chose to include him in our investigation because his documentary production was noticed. He also took part in one of Doc.TV's contests, as a director.

${ }^{71}$ "Karla Holanda desvenda Kátia », in Papo de cinema, 2013.

72 Promises made in 2018.

${ }^{73}$ Karla Holanda, Ibidem, page 43.

${ }^{74}$ Karla Holanda, Ibid.., page 7.

${ }^{75} 2013$ interview, Ibid. 
${ }^{76}$ Angola, Brazil, Green Cape, Guinea-Bissau, Equatorial Guinea, Mozambique, Portugal, São Tome and Principe, Timor-Leste.

${ }^{77}$ Karla Holanda, Ibid., page 15.

${ }^{78}$ Karla Holanda, Ibid., pp. 266-268.

${ }^{79} 2016$ interview, Ibid..

80 "The Pontos de Cultura program aimed at institutional strengthening and recognition of small Brazilian structures with a cultural vocation. The idea was to 'reveal' the initiatives already existing in Brazilian territory and to support their development through financial aid, material and institutional support, without imposing constraints on them in terms of the content of their activities. (...) including associations, cooperatives, unions, private non-profit foundations, public schools, parents and teachers, public interest groups or social organizations. Each Ponto, which signs an agreement with the State for a period of three years, receives a grant of $\mathrm{R} \$ 180,000$ (approximately 27,000 euros) allocated in three installments, in addition to a multimedia kit Source: Ellen Heyward, "Os puntos de cultura, a new model of decentralized cooperation between Brazil and the EU?", In Culture Europe International, Special Brazil, 2012. Unfortunately, a certain number of Pontos have had to close since this implementation.

${ }^{81}$ Against 15 to 18 reais per person, in the classic theaters (2,29 up to $\left.2,75 €\right)$.

${ }^{82}$ Karla Holanda, Ibid.., page 43.

${ }^{83}$ Karla Holanda, Ibid., pp. 266-268.

${ }^{84}$ Karla Holanda, Ibid., page 54.

${ }^{85} 2013$ interview, Ibid..

${ }^{86}$ Contribution for the Development of National Cinematography.

${ }^{87}$ Source: Emmanuel Rufi (2019), "Les chiffres en trompe-I'oeil du cinéma brésilien ", in INA, La revue des médias. According to this article, Rio Filme (a public company of the State of Rio) launched in February 2013 an automatic support program for Carioca producers.

${ }^{88}$ Who can go from two to nine years, to get the funding.

${ }^{89}$ The film retraces the political and personal perception of the director, vis-a-vis the events which led from the election of Lula, to the emplacement of Dilma Roussef, then to the election of Jair Bolsonaro.

${ }^{90}$ A democracia em vertigem nomination sparked heated controversy in Brazil: in the face of cheers from the left, Roberto Alvim, then Special Secretary for Culture in the Bolsonaro government, told Folha de São Paulo: "If it had been in a fictional category, the nomination would have been correct. (...) This shows that the cultural war is being waged not only here, but also internationally." (Sources: Agence France Presse of January 13, 2020, Office Box of February 10, 2020). Roberto Alvim was dismissed on January 17, 2020, for paraphrasing a speech by Josef Goebbels, 3rd Reich Minister for Education and Propaganda. Actress Regina Duarte was subsequently invited to be Special Secretary of Culture. She left this post on May 2020; she would have refused to undertake the cultural crusade against the ideas of the left as required by the president. She was replaced by Mario Frias.

${ }^{91}$ Special thanks to: Karla Holanda, Christina Ferraz Musse, Ellen Heyward.

Thanks to: Erika Campelo, Elsa Chabrol, Ridha Ennafaa, Mariana Ferraz Musse, Patricia Mont-Mór, Geraldo Nunes, Juliana Reis, Cristiano Rodriguez, Liv Sovik, Alfredo Suppia, Glaucia Villas Bôas. 


\section{References}

Books and book chapters, academic works

Association des cinéastes documentaristes (Addoc). (2012). Le temps dans le documentaire au cinéma, L'Harmattan : Paris.

Autissier, A.M., Nunes, G et Ennafaa, R. (Eds). (2012). France-Brésil, échanges intellectuels et artistiques. Repères historiques et prospectifs, Le Fil d'Ariane, Paris 8 Institute of European Studies: Saint-Denis.

Autissier, A.M et Heyward, E. (Eds). (2012). Culture Europe International, Special Brazil: Saint-Denis.

Bernardet, J-C. (2003). Cineastas e Imagens do Povo, Companhia das letras: São Paulo.

Canclini, N.G. (1989). Culturas híbridas: Estrategias para entrar y salir de la modernidad, Grijalbo: México.

Canclini, N.G. (2010). La sociedad sin relato. Antropología y estética de la inminencia, Katz editores: Montevideo.

Guimarães, G.C. (2014). Eduardo Coutinho et la recréation du documentaire brésilien, Éditions Universitaires Européennes : Sarrëbruk.

Des, S. (2004). Brésil, l'atelier des cinéastes, L'Harmattan : Paris.

Elinaldo Teixeira, F (Ed). (2004). Documentário no Brasil: Tradicão e transformacão, Summus Editorial: São Paulo.

Ferraz Musse, M. (2011). Margens nada plácidas: documentário, entrevista, alteridade e identidades, Master's thesis in Communication under the leadership of Professor Dr. Aluizio Trinta: Federal University of Juiz da Fora.

Gauthier, G. (2015). Le documentaire, un autre cinéma. Histoire et création, Armand Colin: Paris

Holanda, K. (2008). Documentário nordestino. Mapeamento, historia e análise, Annablume editora: São Paulo.

Holanda, K. (2017). DOCTV: a producão indépendante na televisão. Um projeto de regionalizacão do governo Lula, Novas Edições Académicas: Beau Bassin, Mauritius

Lins, C. (2004). O documentário de Eduardo Coutinho: Televisão, cinema e vídeo, Jorge Zahar Editor: Rio de Janeiro.

Lins, C. e Mesquité, C. (2008). Filmar o real: Sobre o documentário brasileiro contemporaneo, Jorge Zahar Editor: Rio de Janeiro.

Picard, A (Ed). (2018). Qu'est-ce que le réel? /What is real? Des cinéastes prennent position/ Filmmakers weigh in (40th anniversary of Festival du Réel), Éditions Cinéma du réel: Paris.

Furtado, G.P. (2019). Documentary filmmaking in contemporary Brasil: cinematic archives of the present, Oxford University Press: Oxford.

Ribeiro da Silva Tavares, M. (2011). Helena Solberg: trajetoria de uma documentarista, PhD under the leadership of Professor D. Evandro Jose Lemos da Cunha, Federal University of Minas Gerais: Belo Horizonte.

Silva, P.H (Ed). (2017). Documentário brasileiro, Editorial Letramento e Livraria: Belo Horizonte - in cooperation with Abraccine (Associacão de Críticos de cinema) and TV Brasil.

Waugh, T. (2016). The conscience of cinema: the films of Joris Ivens 1912-1989, Amsterdam University Press: Amsterdam.

Araujo, J.Z. (2019). A negãçao do Brasil. O negro na televisão brasileira, Editorial Senac: São Paulo 


\section{Articles}

Earp, F e Sroulevich, H. (2008). "O comportamento do consumidor de produtos culturais e os combos de entretenimento", in Victor A. Melo ed. Lazer: aspectos históricos, configurações contemporâneas, Editora Alínea: São Paulo.

Earp, F e Sroulevich, H. (2018). "O mercado do cinema no Brasil", in Políticas culturais : Reflexões e acões, ed. Casa de Rui Barbosa, Itaú cultural: Rio de Janeiro.

Fernandes, C et Larroz, E. (2009). "Fragments d'un abécédaire: documentaires en Amérique latine au XXle siècle », in CMHLB, Caravelle n92, Presses universitaires du Midi: Toulouse, 7-12.

Monte-Mór, P. (2005). "Religião e filmes documentários no Brasil", in Revista Chilena de Antropología Visual $n^{\circ} 5,133-142$.

De Carvalho, H.O.T (2017). « Santo Forte : um diálogo entre Eduardo Coutinho e a historia oral », in XXI Socine, O estado da crítica, Paraíba Federal University, 357-363.

Rufi, E. (2019). « Les chiffres en trompe-l’oeil du cinéma brésilien », in INA, La revue des médias.

Xavier, I. (2015). «Des façons d'écouter dans un média visuel. Le mouvement du documentaire au Brésil », in Agone 2015/2, n57, 65-90. 